\title{
1001 Listes: Strategic Breakthroughs by a Low-Tech Company in a High-Tech World
}

\author{
Chris Kimble and Isabelle Bourdon
}

\begin{abstract}
Most articles on strategic breakthroughs tend to concentrate on large, high-tech organizations. Yet the French firm 1001 Listes, which creates and manages wedding lists, has shown that it is possible for even a relatively small organization to generate strategic breakthroughs with standard off-the-shelf information technology. Its experience highlights two points that previous studies have overlooked: Breakthrough strategies are based on innovations in business models as well as innovations in technology, and breakthrough strategies may actually reduce a company's reliance on high-tech solutions as a means of maintaining its competitive advantage. Using Henderson and Venkatraman's (1993) model of strategic alignment, this article also outlines the nature of breakthrough strategies.
\end{abstract}

\section{Introduction}

The concept of breakthrough strategies (Fraser, 2007; Markides, 2000), which maintains that an organization is able to make such a radical change in the way it does business that it effectively rewrites the rules of the game, has become increasingly popular in strategic management literature. Most often associated with such organizations as Dell, Amazon, and eBay, the idea involves significant technological innovation. But need this always be the case? What role does information technology (IT) play in new breakthrough strategies? In particular, can a relatively small company achieve a strategic breakthrough in a mature market using relatively standard technologies?

The experiences of 1001 Listes, a French company that creates and manages wedding lists, demonstrates that it is possible for an organization to achieve a strategic breakthrough using standard off-the-shelf technologies. An analysis of the nature of breakthrough strategies and the way they fit with the notion of IT/business strategic alignment indicates that breakthrough strategies are based more upon innovations in business models than innovations in technology. It also shows that, in contrast to the more established view, breakthrough strategies might actually reduce a company's reliance on advanced technologies as a means of maintaining a competitive advantage. The relationship between IT and strategy is always in a state of flux, with the outcome at any particular point in time being shaped by a variety of factors.

\section{An Introduction to Breakthrough Strategies and Strategic Alignment}

This section reviews the notion of breakthrough strategy and examines its relationship with the idea of strategic alignment using Henderson and Venkatraman's (1993) model of strategic alignment.

\subsection{What Is a Breakthrough Strategy?}

The notion of a breakthrough strategy is straightforward: If a company is able to pioneer some form of innovation that is so radical that it disrupts the way an existing market operates, it creates a completely new set of rules that only it understands and can follow. Such innovations involve a fundamental change in the way things are done: in short, a complete reconceptualization of the existing business model. Such strategies are said to be about changing the rules of the game rather than playing it better. If a company can achieve this, it is able to "break through" a competitive barrier, change the basis of competition, and

C. Kimble and I. Bourdon. 1001 Listes: Strategic breakthroughs by a low-tech company in a high-tech world. Global Business and Organizational Excellence, 31(3), 2012, pp. 58-68.

DOI: $10.1002 /$ joe.21424 
create a sustainable competitive advantage that other firms are unable to follow. In practice, breakthrough strategies tend to originate from new companies that are unencumbered by tradition and an established way of doing things; in practice, these are often high-tech companies or companies that have moved into a new and untapped market (Charitou \& Markides, 2003; Christensen, Johnson, \& Rigby, 2002).

Exhibit 1. Breakthrough Strategy

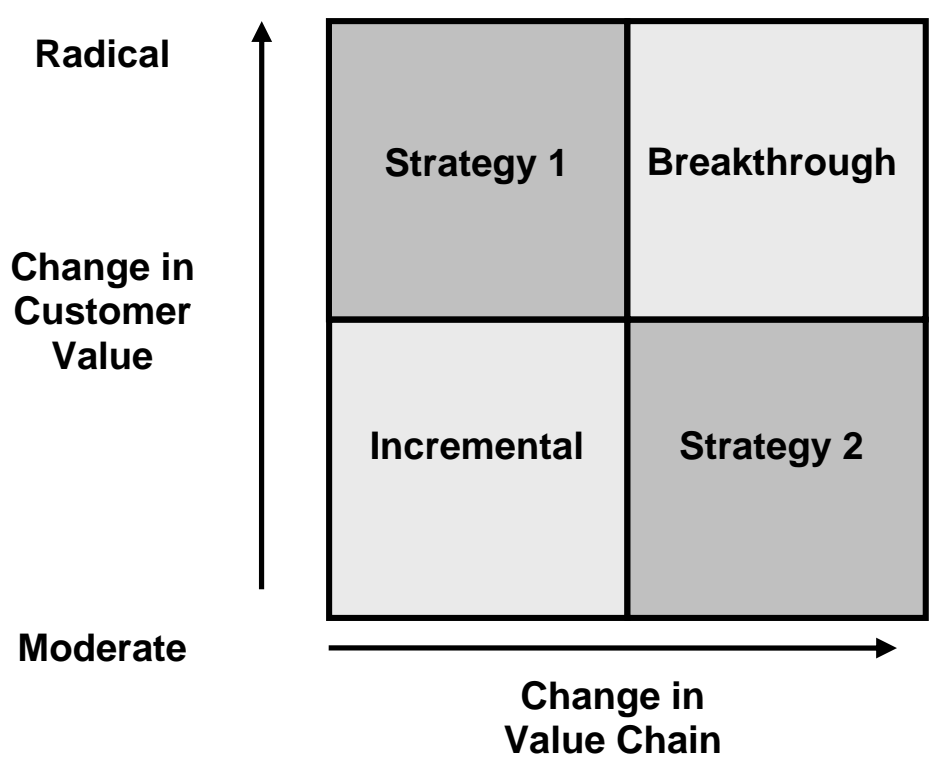

\section{Radical}

Adapted from Kimble, Bourdon, \& Lehmann-Ortega, 2009

Although this idea of moving into the "clear blue oceans" beyond competition (Kim \& Mauborgne, 2005) has been popularized in recent years, the origins of the idea of a strategic breakthrough can be traced to Michael E. Porter's work in the 1980s, in which he argued that if a firm could implement a major technological innovation successfully, then it could open such a gap between its performance and that of its competitors that it could effectively redefine the way the market operates (Porter \& Millar, 1985). Similarly, in the 1990s, Hamel and Prahalad argued that if organizations could "break out of the box" of conventional thinking, they would be able to gain a significant advantage over their competitors (Hamel \& Prahalad, 1994), while Bower and Christensen (1995) argued that technological change could, in itself, disrupt markets.

The emphasis on the disruptive rule-changing nature of breakthrough strategies is stressed by many authors, for example, Govindarajan and Trimble (2004) and Schlegelmilch, Diamantopoulos, and Kreuz (2003). Like Hamel and Prahalad (1994), Friedel and Liedtka (2007) emphasize the importance of questioning existing assumptions, challenging mental models, and connecting seemingly unrelated ideas to create breakthroughs. Markides, who has written extensively on breakthrough strategies, places particular emphasis on the importance of innovations in the business model as a source of strategic breakthroughs: the discovery of a fundamentally different business model in an existing business [that] enlarge[s] the existing economic pie, either by attracting new customers into the market or by encouraging existing customers to consume more. (Markides, 2006, p. 20)

Pin, Métais, and Dumoulin (2003) highlight two sources for such disruptive innovations: a modification in the value proposition for the customer (labeled Strategy 1 in Exhibit 1) and a modification to the value chain of an enterprise (labeled Strategy 2). A company can make a

C. Kimble and I. Bourdon. 1001 Listes: Strategic breakthroughs by a low-tech company in a high-tech world. Global Business and Organizational Excellence, 31(3), 2012, pp. 58-68.

DOI: $10.1002 /$ joe.21424 
disruptive strategic innovation through changing either the customer value axis or the value chain axis, but a successful breakthrough strategy only comes when a company is able to change both.

To summarize, a breakthrough strategy:

- is not about playing the existing game better but about changing the rules of the game;

- involves changes to both the value chain and the customer's value proposition;

- involves a radical or fundamental shift in the way in which things are done; and

- involves a complete reconceptualization or reconfiguration of an existing business model.

For the purposes of this article, a breakthrough strategy is the successful introduction of a radical change in the way a business operates, such that it creates an entirely new way of doing business; success, in this context, is defined in terms of the company's ability to outperform its competitors.

\subsection{Finding Strategic Alignment Between Organizational Goals and IT}

Strategic alignment, in the sense of ensuring an appropriate fit between an organization's business and its IT strategy, has had a central place in the literature since the late 1980s (Ciborra, 1997). The topic of strategic alignment is a difficult area to study, however, because the term is taken to mean several different things and can be seen from a number of different viewpoints. For example, Avison, Jones, Powell, and Wilson (2004) observe:

In contrast to some other areas of IS research, there is debate in the literature about what alignment actually is, why it is needed, how firms may go about the task of becoming aligned, and how it should best be researched. (Avison et al., 2004, p. 224)

Similarly, Hussin, King, and Cragg (2002) note that some studies focus on the process of achieving alignment, others focus on how well firms are able to achieve alignment, and still others focus on how to measure alignment. Papp (1999) claims to have identified 12 different perspectives on strategic alignment present in the literature.

Although there is an ongoing debate about what exactly is meant by strategic alignment, few disagree about its importance. Avison et al. (2004), for example, note that achieving strategic alignment can benefit a firm in three ways: by maximizing return on IT investment, by helping to achieve competitive advantage through IT, and by providing direction and providing it with the flexibility to react to new opportunities.

Although there may not be much agreement on what strategic alignment is or how to study it, there is one point of reference for almost all the literature on the topic: Henderson and Venkatraman's (1993) model (Exhibit 2) which has been described as" ... perhaps the most widely cited of all alignment models" (Chan \& Reich, 2007, p. 303).

C. Kimble and I. Bourdon. 1001 Listes: Strategic breakthroughs by a low-tech company in a high-tech world. Global Business and Organizational Excellence, 31(3), 2012, pp. 58-68.

DOI: $10.1002 /$ joe.21424 
Exhibit 2. Henderson and Venkatraman's Model of Strategic Alignment

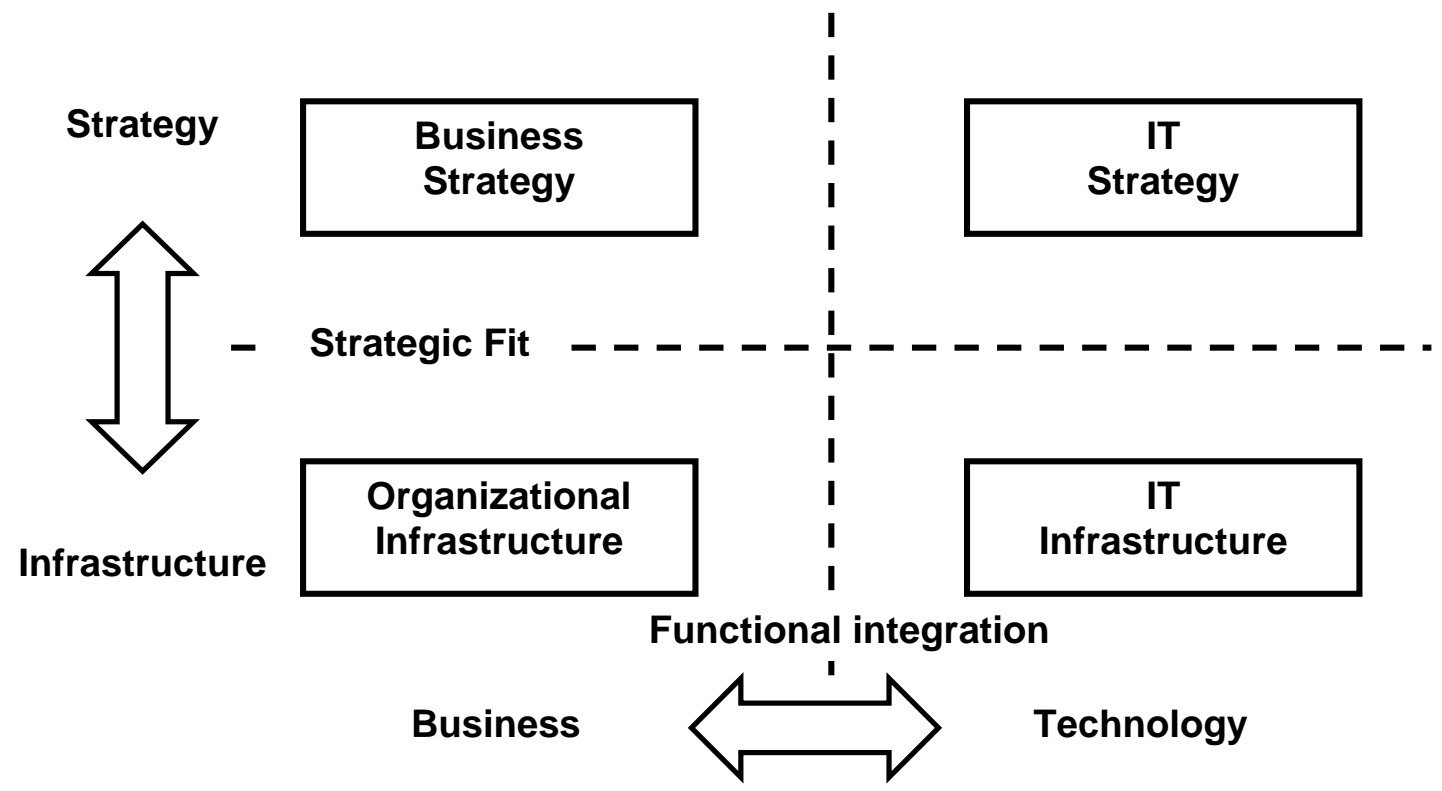

The concept of strategic alignment was originally conceived as a means to link the constantly changing external and internal environment of an organization (Ciborra, 1997). In Henderson and Venkatraman's model, these are represented by business and IT strategy (the external domain), and by organizational and IT infrastructure (the internal domain). They argue that in addition to managing the links between internal and external domains, organizations also need to manage the strategic fit between strategy and infrastructure, and the functional fit between the business and the technology. Thus, the model consists of four interrelated quadrants, where a change in one quadrant requires an adjustment to the remaining three to ensure that both strategic and functional fit is maintained, thus, "strategic alignment is not an event but a process of continuous adaptation and change" (Henderson \& Venkatraman, 1993, p. 473).

Henderson and Venkatraman's model has been the subject of criticism over the years. For example, it has been said that it lacks any theoretical basis (Smaczny, 2001), that it ignores the reality of how businesses function (Papp, 1999), and even that it presents an entirely illusory view of what is meant by alignment (Soetekouw, 2010). Nonetheless, it remains one of the most widely cited examples of how strategic alignment might be achieved.

Henderson and Venkatraman identify four dominant alignment perspectives: strategy execution, technology transformation, competitive potential, and service level. Although either of the disruptive strategies identified in Exhibit 1 could easily be accommodated in the model (for example, as an instance of technology transformation or competitive potential), the basis of a strategic breakthrough is that change takes place simultaneously in two dimensions. If this is the case, both the external strategy dimension of the model (the customer value proposition) and the internal infrastructure dimension (the value chain) need to change at the same time.

\section{Listes: A Low-Tech Breakthrough in a High-Tech World?}

The goal of the case study was to follow the process of building a breakthrough strategy. Thus, the objective was not to validate a preexisting research hypothesis but to explore ideas and develop new propositions. It has been widely noted (Eisenhardt, 1989; Yin, 2003) that case studies are particularly well suited to this task. The data used in this instance was, in part, secondary data from a literature review covering the period 1999-2007 and, in part,

C. Kimble and I. Bourdon. 1001 Listes: Strategic breakthroughs by a low-tech company in a high-tech world. Global Business and Organizational Excellence, 31(3), 2012, pp. 58-68.

DOI: $10.1002 /$ joe.21424 
primary data from semi structured interviews with the founder of the business, the $\mathrm{ClO}$, shop managers, and customers (see Exhibit 3). The data from interviews and the small size of the organization allowed for a much more nuanced view of the role IT played in this case.

\subsection{Background to the Case Study}

The case study is based on 1001 Listes, a small French company that creates and manages wedding lists. The idea of the wedding list first became fashionable in France in the 1960s. At that time, gift registries were run exclusively by the big department stores. By the end of the 1990s, however, the wedding list market had become moribund and the demand for this service had dwindled as the habits and expectations of newlyweds changed. As Pauline d'Orgeval, the founder of 1001 Listes, explained, "The market research that I did in 1998 [revealed] the service at the time was very impersonal [and] newlyweds had the impression that the same list was offered to everybody (...) My goal was to humanize the gift, to concentrate on the affection through personalizing the lists."

\section{Exhibit 3. Data Collected}

\section{Primary data}

Conducted face-to-face and by telephone, interviews lasted between 45 minutes and 2 hours, according to the wishes of the respondents.

\begin{tabular}{|l|l|}
\hline Interviewee & Function \\
\hline Pauline d'Orgeval & CEO of 1001 Listes \\
\hline Patrice Bonhomme & IS Director of 1001 Listes \\
\hline Estelle P. & Customer of 1001 Listes \\
\hline Marie Christine D. & Customer of 1001 Listes \\
\hline Jean V. & Manager of an art gallery and a partner of 1001 Listes \\
\hline Pierre Jean L. & Manager of an interior design store and partner of 1001 Listes \\
\hline
\end{tabular}

\section{Secondary data}

Based on the European press, Factiva, and searches on the Internet, the literature review examined 78 sources, including Les Echos, La Tribune, Capital Finance, Le Figaro, La Vie Financière, Management, The Wall Street Journal, L'Entreprise, L'Expansion, Internet Professionnel, and Le Journal du Net.

Since its creation in late 1999, 1001 Listes has grown to be the third-largest player in the wedding list market in France, just behind Galeries Lafayette and Printemps, the two chains that had traditionally dominated the market. Through 1001 Listes, a personal counselor guides the bride and groom through the process of creating their wedding gift registry and other wedding-related lists. They have complete control over the process via a website or call center. The gifts for the couple are bought using a dedicated loyalty card; 1001 Listes simply deducts a commission of between 15 percent and 50 percent on every transaction (JournalDuNet, 2001). In effect, 1001 Listes acts as an intermediary between the couple, their guests, and a network of more than 500 shops, known as partners. Thanks to this network, 1001 Listes can offer 60,000 products from 2,500 retail outlets in 40 cities in France, Belgium, and the United Kingdom. Like Amazon's "long tail" (Anderson, 2006), 1001 Listes is able to offer a range of gifts that is both more varied and more customized than that which typically is found in department stores.

The case of 1001 Listes constitutes a breakthrough strategy not only because the organization challenged the dominance of the market leaders, but also because it introduced

C. Kimble and I. Bourdon. 1001 Listes: Strategic breakthroughs by a low-tech company in a high-tech world. Global Business and Organizational Excellence, 31(3), 2012, pp. 58-68.

DOI: $10.1002 /$ joe.21424 
a radical change in both the customer value proposition (through offering a very large and highly personalized selection) and in the value chain (through its role as an intermediary rather than a distributor of products).

\section{Listes: The Case Study}

1001 Listes created a business model that was based on the partial dematerialization of the process of managing a wedding gift registry. The means that the company's leaders used to implement this strategy were almost entirely based on off-the-shelf IT. Their IT systems allowed them to engage in three forms of transactions: business-to-consumer, business-tobusiness, and banking.

\subsection{The Role of IT in Creating a Strategic}

\subsubsection{Value Proposition}

The business model developed by 1001 Listes is based largely on innovations associated with customer relationship management technologies. The changes in the customer value proposition concern two types of customers: the bride and groom, who specify what they want, and the guests, who are, in effect, donors who offer money to help fulfill those requirements. The technology that is used is not particularly novel or sophisticated (mainly Java and Sybel databases), but it gives the bride and groom the ability to create and manage most of the activities associated with their wedding list.

For the bride and groom, the technology also allows them to deal with the other aspects of the marriage - for example, wedding invitations, maps, acknowledgments, and the booking of hotel rooms (if reserved with a partner organization). In addition, it allows them to deal with the more public aspects of their marriage, such as the display of photographs online and the creation of a public blog or website.

This set of relatively simple technologies also offers new possibilities for the guests. They can pay for gifts from the wedding registry online, via a call center, or directly in a shop; choose to present the gifts with a selection of images; and even choose to deliver the gifts themselves.

The final piece in the jigsaw puzzle is the addition of another standard technology: that of electronic payment by credit card. 1001 Listes provides a loyalty card that can be used to pay for goods. This allows both the bride and groom and their guests to collect credit points for purchases they make, and creates a link to 1001 Listes and their partner organizations that continues after the wedding celebrations. The role of IT in creating the value proposition for the breakthrough strategy of 1001 Listes is summarized in Exhibit 4.

\subsection{The Role of IT in Creating a Strategic Value Architecture}

By taking an intermediary's role, the value chain of 1001 Listes became much more streamlined than that of a department store, which also had to deal with the buying, storage, and delivery of the gifts in addition to organizing the list and the purchases. Streamlining processes and making them more efficient changed the whole value architecture of the enterprise. Again, IT played a part in this process.

For the partners, the systems ensured the effective management of product categories and contractual relationships. It also modified the value architecture associated with the customers and donors, since the system allowed customers to manage processes directly rather than requiring the stores or 1001 Listes to manage them.

C. Kimble and I. Bourdon. 1001 Listes: Strategic breakthroughs by a low-tech company in a high-tech world. Global Business and Organizational Excellence, 31(3), 2012, pp. 58-68.

DOI: $10.1002 /$ joe.21424 
The act of purchasing goods from a partner is also innovative and is sustained by IT. Every customer is given a 1001 Listes card that can be used online, directly in any of the partner's shops, and at the call centers and some of the big stores (for example, Darty or Habitat). In effect, the payment card becomes a common thread that links all the players before, during, and after the wedding.

Thus, the success of 1001 Listes is based not only on its use of IT to construct a platform for e-commerce, but also on its business model, which facilitates the links between the bride and groom, donors, payees, and the providers of financial services. This is summarized in Exhibit 5.

Exhibit 4. The Role of IT in Implementing the Breakthrough Strategy of 1001 Listes (Value Proposition)

\begin{tabular}{|c|c|c|}
\hline $\begin{array}{l}\text { Modification of the } \\
\text { Value Proposition }\end{array}$ & Use of IT & Functionalities and Effects \\
\hline \multirow{12}{*}{$\begin{array}{l}\text { For the future bride } \\
\text { and groom }\end{array}$} & \multirow{3}{*}{ Constitution of lists } & $\begin{array}{l}\text { Creation of an online wedding list, } \\
\text { modification from examples of existing lists, } \\
\text { galleries of shops, a search engine with more } \\
\text { than } 60,000 \text { items }\end{array}$ \\
\hline & & $\begin{array}{l}\text { Products and selected services are described } \\
\text { and documented }\end{array}$ \\
\hline & & $\begin{array}{l}\text { Standard wedding lists can be built around } \approx \\
100 \text { pre-defined themes }\end{array}$ \\
\hline & \multirow{3}{*}{$\begin{array}{l}\text { Management of the } \\
\text { wedding lists }\end{array}$} & $\begin{array}{l}\text { Real-time alerts for reserved gifts and } \\
\text { payments received }\end{array}$ \\
\hline & & $\begin{array}{l}\text { Follow-up of the purchases (detail and } \\
\text { amount) and of the account for the list }\end{array}$ \\
\hline & & Management of acknowledgments online \\
\hline & $\begin{array}{l}\text { Multi Boutique } \\
\text { Loyalty Card }\end{array}$ & $\begin{array}{l}\text { A loyalty card that allows the accumulation of } \\
\text { points for every purchase made at partners' } \\
\text { stores }\end{array}$ \\
\hline & \multirow{3}{*}{$\begin{array}{l}\text { Management of the } \\
\text { factual side of the } \\
\text { marriage }\end{array}$} & $\begin{array}{l}\text { Management of information about guests, } \\
\text { sending invitations by e-mail to guests with a } \\
\text { link that can be followed up automatically }\end{array}$ \\
\hline & & Management of the budget \\
\hline & & Management of acknowledgments \\
\hline & $\begin{array}{l}\text { Management of the } \\
\text { public aspect of the } \\
\text { marriage }\end{array}$ & $\begin{array}{l}\text { The creation of a personal blog or web site for } \\
\text { the marriage }\end{array}$ \\
\hline & Newsletter & $\begin{array}{l}\text { Regular information for the bride and groom } \\
\text { on changes in the shops and showrooms }\end{array}$ \\
\hline \multirow{4}{*}{ For the guests } & \multirow{4}{*}{$\begin{array}{l}\text { Management of the } \\
\text { gifts }\end{array}$} & $\begin{array}{l}\text { Guests can consult wedding lists and view } \\
\text { items on a web site }\end{array}$ \\
\hline & & $\begin{array}{l}\text { The guests can buy the gifts online, in shops, } \\
\text { or via the call centers }\end{array}$ \\
\hline & & $\begin{array}{l}\text { The guests can leave online messages for the } \\
\text { bride and groom }\end{array}$ \\
\hline & & $\begin{array}{l}\text { The guests receive a notification of the } \\
\text { delivery of their gifts by e-mail }\end{array}$ \\
\hline
\end{tabular}

The case of 1001 Listes clearly illustrates the role that relatively standard low-tech solutions can play in creating a breakthrough strategy. In addition, as indicated earlier, the interviews

C. Kimble and I. Bourdon. 1001 Listes: Strategic breakthroughs by a low-tech company in a high-tech world. Global Business and Organizational Excellence, 31(3), 2012, pp. 58-68.

DOI: $10.1002 /$ joe.21424 
and the relatively small size of the business provided some further insights into the nature of the dynamics between IT and strategic innovation.

\subsection{The Relationship Between IT and Strategy}

In addition to showing how breakthrough strategies depend as much on the business model as they do on the innovative use of IT, the case of 1001 Listes demonstrates something of the interactive nature of the relationship between IT and strategy. Henderson and Venkatraman (1993), among others, have stressed the way in which strategy and IT interact with each other as an aspect of theory, but, perhaps because of the way the data were gathered, this interaction became directly apparent. One of the best illustrations of this is provided by the changing attitudes of the public to the use of the Internet. When 1001 Listes was first launched, it had a small number of showrooms as well as a call center and website. Interaction with customers in the showrooms helped 1001 Listes ensure that its use of IT and its business strategy were kept aligned.

Exhibit 5. The Role of IT in Implementing the Breakthrough Strategy of 1001 Listes (Value Architecture)

\begin{tabular}{|c|c|c|}
\hline $\begin{array}{l}\text { Modification of the } \\
\text { Value Architecture }\end{array}$ & Use of IT & Functionalities and Effects \\
\hline \multirow{3}{*}{$\begin{array}{l}\text { Management of the } \\
\text { relationship with } \\
\text { partners }\end{array}$} & \multirow{3}{*}{$\begin{array}{l}\text { Relationship } \\
\text { management }\end{array}$} & Creation of a database of contracts \\
\hline & & $\begin{array}{l}\text { Management of the partner's account } \\
\text { (margin, commissions, rate of discount, } \\
\text { management of balances, etc.) }\end{array}$ \\
\hline & & $\begin{array}{l}\text { Automatic documentation of the products } \\
\text { that have been selected }\end{array}$ \\
\hline \multirow{5}{*}{$\begin{array}{l}\text { Constitution of the } \\
\text { wedding list }\end{array}$} & \multirow{5}{*}{$\begin{array}{l}\text { The creation of lists } \\
\text { enables }\end{array}$} & Different types of lists \\
\hline & & The use of call centers \\
\hline & & A search engine with 60000 items \\
\hline & & The creation of a gallery of shops \\
\hline & & A system of classification \\
\hline \multirow{2}{*}{$\begin{array}{l}\text { Management of the } \\
\text { list }\end{array}$} & \multirow{4}{*}{$\begin{array}{l}\text { Managing the } \\
\text { relationship with the } \\
\text { donors }\end{array}$} & $\begin{array}{l}\text { Automated management by the bride and } \\
\text { groom }\end{array}$ \\
\hline & & Automatic updating of the lists \\
\hline \multirow[b]{2}{*}{ Collection of gifts } & & Online visualization of the list with photos \\
\hline & & $\begin{array}{l}\text { Delivery arranged online or via the call } \\
\text { center or directly from the shops }\end{array}$ \\
\hline \multirow{3}{*}{$\begin{array}{l}\text { Purchase of gifts by } \\
\text { the bride and groom }\end{array}$} & \multirow{4}{*}{ Payment card } & $\begin{array}{l}\text { Guaranteeing the transactions through an } \\
\text { outside agency }\end{array}$ \\
\hline & & $\begin{array}{l}\text { The bride and groom have a payment card } \\
\text { that can be used for online purchases, in the } \\
\text { partner's shops, or in the showrooms }\end{array}$ \\
\hline & & Management of credit authorization \\
\hline $\begin{array}{l}\text { Payment of the } \\
\text { supplier }\end{array}$ & & Management of invoices \\
\hline
\end{tabular}

The director of information systems at 1001 Listes explained, "When Pauline d'Orgeval created 1001 Listes, the first showrooms were very Internet oriented. It [the Internet] frightened people. Afterwards, all references to Internet were removed. In the showrooms in 1999-2000, there were no more computer screens; [however] since 2005, they have come back in strength with changes in the notion of Internet and in notions of independence regarding the management of the event."

C. Kimble and I. Bourdon. 1001 Listes: Strategic breakthroughs by a low-tech company in a high-tech world. Global Business and Organizational Excellence, 31(3), 2012, pp. 58-68.

DOI: $10.1002 / j o e .21424$ 
Similarly, Pauline d'Orgeval explains, "after the first couple of years, one has a very different view of the problem, one begins to be known, people almost have a reflex to go to 1001 Listes as much as that for Printemps, Galeries Lafayette, etc. This problem of trust seems to have been resolved; 80 percent of the gifts are bought on the Internet. There is not the apprehension anymore."

The relationship between IT and strategy is not fixed but in a state of perpetual change. The so-called democratization of the Internet that took place in the early part of this century allowed 1001 Listes to modify its value architecture by placing Internet technologies at the heart of operations. In this case, the link between IT and strategy was not a simple linear link but a succession of co-alignments (see Exhibit 6).

\section{Some Lessons From the Case Study}

The prime focus of this research was on analyzing a specific example of a strategic breakthrough, not the process that preceded it. It should be noted, however, that the company that was studied, 1001 Listes, was a start-up (albeit one that was moving into a mature market) that was unencumbered by a legacy business model or IT. Nonetheless, this case study provides some useful insights into the role played by IT in strategic breakthroughs.

Exhibit 6. The Dynamic Interaction Between IT and Strategy

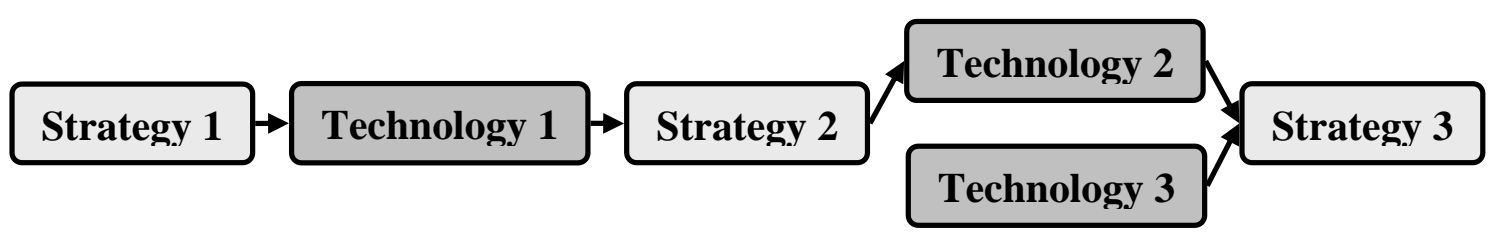

Perhaps one of the most noteworthy aspects of this case is that the company was able to implement a strategic innovation that allowed it to break away from its competitors by using standard off-the-shelf technologies. Although the role played by IT in creating and sustaining competitive advantage has long been recognized (Porter \& Millar, 1985), technological innovation is more often associated with the development of new technologies rather than the innovative use of technologies that already exist. What does this tell us about the relationship between breakthrough strategies and IT?

\subsection{Breakthrough Strategies Are Not Built on Technology Alone}

The case study provides a clear indication that strategy cannot be built on technology alone. 1001 Listes did not have the wedding list market to itself; there were a number of other companies trying to develop the market for comparable services. For example, a company called á lafolie.com adopted the same basic business model of an intermediary as 1001 Listes but failed. Á lafolie.com was created in the same year as 1001 Listes but decided to base its business on the Internet. Even though it was reported to have invested seven times more in the project than 1001 Listes did, it was unable to make a return (N'Kaoua, 2001).

The reason put forward for this was that the acceptance of the Internet at that time was too low for á lafolie.com to succeed. In contrast, the closeness of 1001 Listes to its potential market made the organization much more aware of the necessity to help customers with the process. This was, in part, the reason for the introduction of a personal counselor. The heart of the success of 1001 Listes was its business model rather than its use of technology.

C. Kimble and I. Bourdon. 1001 Listes: Strategic breakthroughs by a low-tech company in a high-tech world. Global Business and Organizational Excellence, 31(3), 2012, pp. 58-68.

DOI: $10.1002 /$ joe.21424 


\subsection{Breakthrough Strategies May Decrease Reliance on High Technology}

One of the biggest problems facing any systems designer is that of how to deal with changing requirements. Making changes in established systems is a minefield that most organizations try to avoid. The risks associated with making major changes in the IT infrastructure of a large company are significant, and, for most, strategic innovations based on development of IT appear to be a "one off." It is interesting to note, therefore, that the development of the systems in this case seems to have been evolutionary and incremental with the IT infrastructure of the company undergoing a significant change with the move to the Internet in 2005. Taken in conjunction with the problems typically associated with making major changes to complex systems once they are in place, this may indicate that companies that can achieve a breakthrough strategy of this type may also benefit from the fact that, thereafter, they are able to use less sophisticated, and hence more easily modifiable, systems.

\subsection{The Interaction Between Technology and Strategy}

As already indicated, there is a general acceptance that the link between technology and strategy is an ongoing process, and this theme has appeared repeatedly in the literature. In empirical studies, it has been named as a processual model of change by Dawson (1994), an interactionist model by Kimble and McLoughlin (1995), and an integrationist model by Boddy (2000). In the case of 1001 Listes, it was also clear that the founder's vision of the founder also played a significant role. Charitou and Markides (2003) observed that radical strategic innovations usually occur in small start-up businesses. The fact that 1001 Listes was founded by one person who was able to steer the business from its inception clearly played a role in both the choice of strategy and the choice of technology.

Making Substantial Gains Through Simple Means The case study of 1001 Listes has been useful in examining various aspects of the links between IT and breakthrough strategy. It has provided insights into the way companies can use comparatively simple IT solutions to obtain a substantial competitive advantage and has shifted the focus from the technology itself to what the technology does (that is, the business model).

One question this case study did not deal with is the problem of being able to continue to evolve and stay ahead of the competition. As Teece notes, "In practice, successful business models very often become, to some degree, 'shared' by multiple competitors" (Teece, 2010, p. 179). In order for a business model to continue to provide competitive advantage in the long term, it must be clearly differentiated from other business models and difficult for others to imitate. Can a long-term advantage really be built on standard technology that is available to everybody? Does the indication from this case study that breakthrough strategies can reduce the dependence on high-tech solutions hold in other cases? Only further studies of the ways in which changes can be made to existing IT to achieve strategic breakthroughs can help answer these questions.

\section{References}

Anderson, C. (2006). The long tail: Why the future of business is selling less of more. New York, NY: Hyperion.

Avison, D., Jones, J., Powell, P., \& Wilson, D. (2004). Using and validating the strategic alignment model. The Journal of Strategic Information Systems, 13, 223-246.

Boddy, D. (2000). Implementing interorganizational IT systems: Lessons from a call centre project. Journal of Information Technology, 15, 29-37.

C. Kimble and I. Bourdon. 1001 Listes: Strategic breakthroughs by a low-tech company in a high-tech world. Global Business and Organizational Excellence, 31(3), 2012, pp. 58-68. DOI: $10.1002 /$ joe.21424 
Bower, J. L., \& Christensen, C. M. (1995). Disruptive technologies: Catching the wave. Harvard Business Review, 73(1), 43-53.

Chan, Y. E., \& Reich, B. H. (2007). IT alignment: What have we learned? Journal of Information Technology, 22, 297-315.

Charitou, C. D. \& Markides, C. C. (2003). Responses to disruptive strategic innovation. MIT Sloan Management Review, 44(2), 55-63.

Christensen, C. M., Johnson, M. W., \& Rigby, D. K. (2002). Foundations for growth: How to identify and build disruptive new businesses. MIT Sloan Management Review, 43(3), 22-31.

Ciborra, C. U. (1997). De profundis? Deconstructing the concept of strategic alignment. Scandinavian Journal of Information Systems, 9(1), 67-82.

Dawson, P. M. B. (1994). Organizational change: A processual approach. London, UK: Paul Chapman.

Eisenhardt, K. M. (1989). Building theories from case study research. Academy of Management Review, 14, 532-550.

Fraser, H. M. A. (2007). The practice of breakthrough strategies by design. Journal of Business Strategy, 28(4), 66-74.

Friedel, R., \& Liedtka, J. (2007). Possibility thinking: Lessons from breakthrough engineering. Journal of Business Strategy, 28(4), 30-37.

Govindarajan, V., \& Trimble, C. (2004). Strategic innovation and the science of learning. MIT Sloan Management Review, 45(2), 67-75.

Hamel, G., \& Prahalad, C. K. (1994). Competing for the future. Boston, MA: Harvard Business School Press.

Henderson, J. C., \& Venkatraman, N. (1993). Strategic alignment: Leveraging information technology for transforming organizations. IBM Systems Journal, 31, 472-484.

Hussin, H., King, M., \& Cragg, P. (2002). IT alignment in small firms. European Journal of Information Systems, 11, 108-127.

JournalDuNet. (2001). 1001 Listes adopte une fide' lisation "click \& mortar." Le Journal du Net. Retrieved from http:// www.journaldunet.com/0004/0102/0102261001listes.shtml

Kim, W. C., \& Mauborgne, R. (2005). Blue ocean strategy: How to create uncontested market space and make competition irrelevant. Boston, MA: Harvard Business Press.

Kimble, C., Bourdon, I., \& Lehmann-Ortega, L. (2009). Business meta-models and the saga of business-IT strategic alignment. Paper presented at the Americas Conference on Information Systems (AMCIS 2009), San Francisco, CA.

Kimble, C., \& McLoughlin, K. (1995). Computer based information systems and managers work. New Technology, Work and Employment, 10(1), 56-67.

Markides, C. C. (2000). All the right moves: A guide to crafting breakthrough strategy. Boston, MA: Harvard Business School Press.

Markides, C. C. (2006). Disruptive innovation: In need of better theory. Journal of Product Innovation Management, 23(1), 19-25.

N'Kaoua, L. (2001, November 26). Europ web, Atlas Venture et 3i se retirent d'Alafolie.com. Les Echos, p. 109.

Papp, R. (1999). Business-IT alignment: Productivity paradox payoff? Industrial Management \& Data Systems, 99, 367-373.

C. Kimble and I. Bourdon. 1001 Listes: Strategic breakthroughs by a low-tech company in a high-tech world. Global Business and Organizational Excellence, 31(3), 2012, pp. 58-68.

DOI: $10.1002 /$ joe.21424 
Pin, R., Métais, E., \& Dumoulin, R. (2003). Vers un de' passement de l'antinomie entre rupture et continuité : Le cas Valéo. Paper presented at the Xllème conférence de I'AIMS, Carthage, Tunisia.

Porter, M. E., \& Millar, V. A. (1985). How information gives you competitive advantage. Harvard Business Review, 63(4), 149-160.

Schlegelmilch, B. B., Diamantopoulos, A., \& Kreuz, P. (2003). Strategic innovation: The construct, its drivers and its strategic outcomes. Journal of Strategic Marketing, 11(2), 117132.

Smaczny, T. (2001). Is an alignment between business and information technology the appropriate paradigm to manage IT in today's organisations? Management Decision, 39, 797-802.

Soetekouw, A. A. (2010). Alignment revisited. Amsterdam, the Netherlands: University of Amsterdam Business School.

Teece, D. J. (2010). Business models, business strategy and innovation. Long Range Planning, 43(2-3), 172-194.

Yin, R. K. (2003). Case study research: Design and methods. Thousand Oaks, CA: Sage. 